\title{
DESIGN, SYNTHESIS, ANTIMICROBIAL AND ANTIFUNGAL ACTIVITIES OF NEW 1,2,4-TRIAZOLE DERIVATIVES CONTAINING $1 H$-TETRAZOLE MOIETY
}

\author{
1H-TETRAZOL IÇEREN YENİ 1,2,4-TRİAZOL TÜREVLERININN TASARIMI, SENTEZİ, \\ ANTIMIKKROBIYYAL VE ANTIFUNGAL AKTIVITELERI
}

Yuliia FROLOVA ${ }^{1, *}$, Andriy KAPLAUSHENKO ${ }^{1}$, Nataliya NAGORNAYA ${ }^{2}$

${ }^{1}$ Zaporizhzhya State Medical University, Faculty of Pharmacy, Department of Physical and Colloidal Chemistry, Zaporizhzhya, Ukraine

${ }^{2}$ Zaporizhzhya State Medical University, Faculty of Pharmacy, Department of Medicinal Preparations Technology, Zaporizhzhya, Ukraine

\begin{abstract}
Objective: Antimicrobials and antifungals are the most acquired drugs in the world. Today, it becomes necessary to create new drugs with antimicrobial and antifungal effect. The purpose of our research is the synthesis of new series of 5-(1H-tetrazole-1-yl)-4H-1,2,4-triazole-3-amine, the establishment of physicalchemical, antimicrobial and antifungal properties for all synthesized compounds.

Material and Method: 5-(1H-tetrazole-1-yl-methyl)-4H-1,2,4-triazole-3-yl-1-(alkyl-, aryl-)-methanimines were synthesized by reacting of 5-(1H-tetrazole-1-yl-methyl)-4H-1,2,4-triazole-3-amine with aldehydes in acetic acid. Then, sodium borohydride was selected as a reducing agent, which allowed for the restoration of the double bond. The structures of synthesized compounds were confirmed by IR, ${ }^{1} H$ NMR and mass spectra. The synthesized compounds were evaluated for antimicrobial and antifungal activity by "serial dilutions" method.

Result and Discussion: During the synthetic studies the new series of 22 compounds were obtained. The 5(1H-tetrazole-1-yl-methyl)-4H-1,2,4-triazole-3-yl-1-(5-nitrofuran-2-yl)methanimine was observed to be most possessing good antimicrobial and antifungal activity and has exceeded the reference standard for Staphylococcus aureus (12,5/25 mg/ml), Escherichia coli (50/100 mg/ml), Pseudomonas Aeruginosa (100/200 $\mathrm{mg} / \mathrm{ml})$, Candida albicans $(50 / 50 \mathrm{mg} / \mathrm{ml})$.
\end{abstract}

Keywords: 1,2,4-triazole, 1 H-tetrazole, antimicrobial and antifungal activity

\footnotetext{
* Corresponding Author/ Sorumlu Yazar: Yuliia FROLOVA

e-mail /e-posta: yuliia_hulina@ukr.net
}

Submitted / Gönderilme: 07.06.2019

Accepted / Kabul: 12.01.2020 


\section{ÖZ}

Amaç: Antimikrobiyal ve antifungal ilaçlar dünyada en yaygın ilaç türlerindendir. Günümüzde mikroplara ve mantarlara karşı yeni ilacın üretilmesine ihtiyaç duyulur. Araştırmamızın amacl, 5-(1H-tetrazol1-il)-4H-1,2,4-triazol-3-amin türevi yeni bileşiklerin sentezi ile sentez edilmiş bileşiklerin fizikokimyasal, antimikrobiyal ve antifungal özelliklerinin tespit edilmesidir.

Gereç ve Yöntem: 5-(1H-tetrazol-1-ilmetil)-4H-1,2,4-triazol-3-il-1-(alkil-, aril-)-metanim, 5-(1Htetrazol-1-ilmetil)-4H-1,2,4-triazol-3-amin'in sirke asidinde aldehitler ile etkileşimi sonucunda sentez edilmiştir. Bir sonraki aşamada indirgen olarak sodyum borohidrür kullanıldı̆̆ için ikili bă̆ yeniden kurulabilmiştir. Sentez edilmiş bileşiklerin yapıları, kızılaltı, nükleer manyetik rezonans ve kütle spektroskopisi ile doğrulanır. Sentez edilmiş bileşikler mikrop ve mantarlara karşı aktivite konusunda serili dilüsyon metodu ile denetlenmiştir.

Sonuç ve Tartışma: Sentetik araştırmaların sonucunda 22 bileşikten oluşan yeni seri elde edilmiştir. 5(1H-tetrazol-1-ilmetil)-4H-1,2,4-triazol-3-il-1-(5-nitrofuran-2-il)metanimin en iyi antimikrobiyal ve antifungal etkisine sahip olup Staphylococcus aureus (12,5/25 mg/ml), Escherichia coli (50/100 mg/ml), Pseudomonas aeruginosa $(100 / 200 \mathrm{mg} / \mathrm{ml})$, Candida albicans $(50 / 50 \mathrm{mg} / \mathrm{ml})$ için karşılaştırmalı ilacı geçtiğini tespit edilmiştir.

Anahtar Kelimeler: 1,2,4-triazol, 1H-tetrazol, antimikrobiyal ve antifungal aktivite

\section{INTRODUCTION}

Piperidinium 2-((5-(furan-2-yl)-4-phenyl-4H-1,2,4-triazol)-3-yl) acetate is the active pharmaceutical ingredient of drug "Tryfuzol" (API). It is used in veterinary as an immunomodulatory agent. It increases the resistance of organisms to viral diseases. Forced degradation conditions create the model influence of various environmental factors on the active substance. In these conditions, various impurities may be formed in the decomposition, which may alter or weaken the biological activity of the active compound, as well as increase toxicity. Thus, it is possible to predict which impurities may be generated during the storage or transportation of drugs containing the investigated API. It will also help to offer conditions for the protection of this substance from the influence of harmful factors. Therefore, this study has a significant relevance.

Methods for investigating force degradation effects have been described in a number of publications [1-6]. Regulatory aspects in Development of Stability-Indicating Methods were presented in the review of Renu Sehrawat $e t$ al. [1]. The condition for stress degradation which usually studied are: acid hydrolysis, base hydrolysis, thermal hydrolysis, oxidation, thermal degradation, photodegradation.

Authors [7] proposed potentiometric titration method for quantitative determination of piperidinium 2-((5-(furan-2-yl)-4-phenyl-4H-1,2,4-triazol-3-yl)thio)acetate in the $1 \%$ and $2.5 \%$ solutions. Method is not selective, and it is not applicable for determination of impurities. Method based on adsorbtion of this API in the ultraviolet region of the spectrum was elaborated [8]. Low selectivity and sensitivity of the method are not permitted to measure of impurities. 
Our HPLC-DAD method of determination of piperidinium 2-((5-(furan-2-yl)-4-phenyl-4H-1,2,4triazol-3-yl)thio)acetate in $1 \%$ solution shown satisfied quality of separation of API from impurities [9]. This work was not contained forced degradation study.

Aim of the research to make forced degradation study of piperidinium 2-((5-(furan-2-yl)-4phenyl-4H-1,2,4-triazol)-3-yl) acetate in active pharmaceutical ingredient, $0.1 \%$ solution and $1 \%$ solution for injection.

\section{MATERIAL AND METHOD}

\section{Chemicals and reagents}

Piperidinium 2-((5-(furan-2-yl)-4-phenyl-4H-1,2,4-triazol)-3-yl)acetate was obtained from Toxicological and Inorganic Chemistry Department. Substance was synthesized and its structure was confirmed by the Parchenko V.V. [10,11]. Acetonitrile qualified "HPLC Super Gradient" (Avantor Performance Materials Poland S.A., Poland), methanoic acid was 100\% (AppliChem GmbH, Germany), ultra-high pure water $\left(18 \mathrm{M} \Omega\right.$ at $\left.25{ }^{\circ} \mathrm{C}\right)$ was prepared by the Direct Q 3UV Millipore (Molsheim, France).

\section{Analytical Instrumentation}

Agilent 1260 Infinity HPLC System (degasser, binary pump, autosampler, thermostat column compartment, DAD). Agilent single-quadrupole mass spectrometer 6120 with electrospray ion source (ESI); OpenLAB Software CDS.

\section{Chromatography conditions}

The chromatography study was carried out by elution with a water-acetonitrile mixture (70:30) with the addition of $0.1 \%$ methanoic acid. Column Zorbax SB-C18, $30 \mathrm{~mm}$ x $4.6 \mathrm{~mm}, 1.8 \mathrm{um}$. Column Temp. $40^{\circ} \mathrm{C}$. Flow rate was $0.400 \mathrm{ml} / \mathrm{min}$.

\section{Mass spectrometry conditions}

Temperature of drying gas was $100^{\circ} \mathrm{C}$. Drying gas (nitrogen) flow rate was $10 \mathrm{l} / \mathrm{min}$. Nebulizing gas (N2) pressure was 53 psig. Mass spectra were obtained at m/z 100-2000. Fragmentation of molecular ions was studied at fragmentor voltage: $100,150,200 \mathrm{~V}$, positive polarity.

\section{Forced degradation conditions}

Samples were taken every day, prepared for injection and injected into HPLC system. Volume of injection for $0.1 \%$ solution was $5 \mathrm{uL}$, for $1 \%$ solution was $0.5 \mathrm{uL}$. Content (\%) was taken from the report of OpenLab CDS Software from Signal of the DAD detector at $276 \mathrm{~nm}$.

Laboratory conditions degradation

Substance and solutions $(0.1 \%, 1 \%)$ were kept at room temperature in laboratory conditions. 


\section{Thermal degradation}

Influence of temperature was studied in the thermostat at the $66{ }^{\circ} \mathrm{C}$ for the $0.1 \%, 1 \%$ solutions and substance. The samples were kept at $66{ }^{\circ} \mathrm{C}$ during 5 days.

\section{Oxidative degradation}

Hydrogen peroxide (3\%) was used for study of the influence of oxidizing agent. About $0.001 \mathrm{~g}$ of API was dissolved in the $1 \mathrm{~mL}$ of $3 \%$ hydrogen peroxide.

\section{Ultraviolet (UV) degradation}

The irradiation was carried out by the luminescent UV lamp, YF UV-9W $365 \mathrm{~nm}$, which radiates in the range of long-wavelength ultraviolet with a maximum radiation of $365 \mathrm{~nm}$. The illumination was measured with a luxmeter and was approximately 2000 lux. Solid substance and solutions with concentrations $0.1 \%, 1 \%$ were studied. Maximal period of exposure was 4 days.

Acid hydrolysis

Influence of acid was studied. About $0.001 \mathrm{~g}$ of API was mixed with the $1 \mathrm{~mL}$ of the $0.1 \mathrm{~mole} / \mathrm{L}$ of $\mathrm{HCl}$.

Alkaline hydrolysis

About $0.001 \mathrm{~g}$ of API was mixed with the $0.1 \mathrm{~mole} / \mathrm{L}$ sodium hydroxide solution.

Preparation of solutions for laboratory conditions degradation study, thermal decomposition study, UV degradation study

Solution with concentration $0.1 \%$ was prepared by dissolution of $0.001 \mathrm{~g}$ of API in $1 \mathrm{~mL}$ of water. Solution with concentration $1 \%$ was prepared according to pharmaceutical preparation " $1 \%$ solution for injections", viz. $0.01 \mathrm{~g}$ of API was dissolved in the $1 \mathrm{~mL}$ of water, 0.0059 of sodium chloride was added.

When the solid substance was studied, $0.001 \mathrm{~g}$ was dissolved in $1 \mathrm{~mL}$ water and $5 \mathrm{uL}$ of solution was injected to the HPLC.

\section{RESULT AND DISCUSSION}

\section{Optimized chromatography conditions}

2-((5-(Furan-2-yl)-4-phenyl-4H-1,2,4-triazol-3-yl)thio)acetic acid was formed in the stream of solvent from the API (salt). Therefore, the detector identified the acid. Thus, API was determined in form of the acid.

Results of the study of the substance decomposition are shown in Table. 1. Mass balance, \% (content of the main substance, \% plus content of degradation products and impurities, \%) in all cases was equaled $100 \%$. 
Table 1. Quantitative content of the piperidinium 2-((5-(furan-2-yl)-4-phenyl-4H-1,2,4-triazol)-3-yl) acetate.

\begin{tabular}{lccccccc}
\hline \multicolumn{1}{c}{ Days } & $\mathbf{0}$ & $\mathbf{1}$ & $\mathbf{2}$ & $\mathbf{3}$ & $\mathbf{4}$ & $\mathbf{5}$ & $\mathbf{6}$ \\
\hline $\begin{array}{l}\text { Terms of decomposition } \\
\text { Laboratory conditions, }\end{array}$ & 99.64 & 99.54 & 99.53 & 99.47 & 99.47 & 99.46 & 99.48 \\
\hline $\begin{array}{l}\text { Laboratory conditions, } 1 \% \\
\text { solution }\end{array}$ & 99.97 & 99.97 & 99.97 & 99.94 & 99.94 & 99.93 & \\
\hline $\begin{array}{l}\text { Alkaline hydrolysis. } 0.1 \mathrm{M} \\
\text { solution of } \mathrm{NaOH}\end{array}$ & 99.64 & 99.58 & 99.66 & 99.64 & 99.64 & 99.61 & 99.66 \\
\hline $3 \% \mathrm{H}_{2} \mathrm{O}_{2}$ & 99.63 & 79.10 & 73.20 & 69.54 & 65.44 & 61.57 & 55.49 \\
\hline $\begin{array}{l}\text { Thermal effect } 66^{\circ} \mathrm{C}, 0.1 \% \\
\text { solution }\end{array}$ & 99.64 & 99.53 & 99.35 & 99.25 & 99.25 & 99.24 & \\
\hline $\begin{array}{l}\text { Thermal effect } 66^{\circ} \mathrm{C}, \\
1 \% \text { solution }\end{array}$ & 99.97 & 99.94 & 99.92 & 99.87 & 99.85 & 99.85 & \\
\hline $\begin{array}{l}\text { Thermal effect } 66^{\circ} \mathrm{C}, \\
\text { substance }\end{array}$ & 99.64 & 99.80 & 99.72 & 99.90 & 99.80 & 99.81 & \\
\hline $\begin{array}{l}\text { UV light irradiation, } \\
\text { solution 0.1\% }\end{array}$ & 99.64 & 97.41 & 89.31 & 77.61 & 56.25 & & \\
\hline $\begin{array}{l}\text { UV light irradiation, } \\
\text { solution 1\% }\end{array}$ & 99.97 & 97.29 & 93.36 & 89.68 & 80.03 & & \\
\hline $\begin{array}{l}\text { UV light irradiation, } \\
\text { substance }\end{array}$ & 99.64 & 99.80 & 99.76 & 99.23 & 99.76 & & \\
\hline
\end{tabular}

\section{Laboratory conditions degradation}

During the storage of the $0.1 \%$ reference API solution in the laboratory conditions, percentage of the substance was decreased about $0.1 \%$ for 6 days. The level of the substance in $1 \%$ solution under these conditions was not changed for 5 days.

\section{Thermal degradation}

Thermal effect $\left(66^{\circ} \mathrm{C}\right)$ on the $0.1 \%$ solution of API leads to its decomposition by approximately $0.4 \%$ over 5 days (Fig.1). Substantial degradation products, however, was not identified.

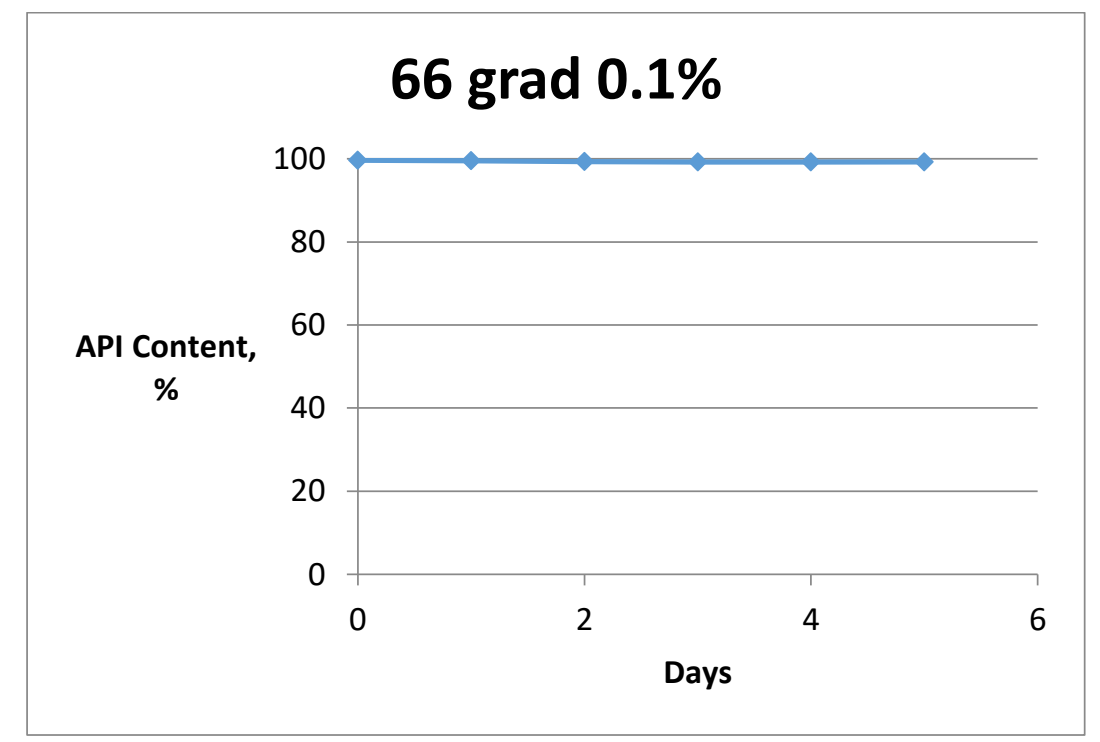

Figure1. The API degradation curve in the $0.1 \%$ solution at a temperature $66{ }^{\circ} \mathrm{C}$ 
At the same time, under the influence of the temperature $\left(66{ }^{\circ} \mathrm{C}\right)$ on the $1 \%$ solution decomposition occurs only about $0.1 \%$ (Fig. 2). During the study of the thermal effect $\left(66^{\circ} \mathrm{C}\right)$ on the solid substance (API) the content of API in a substance was not changed.

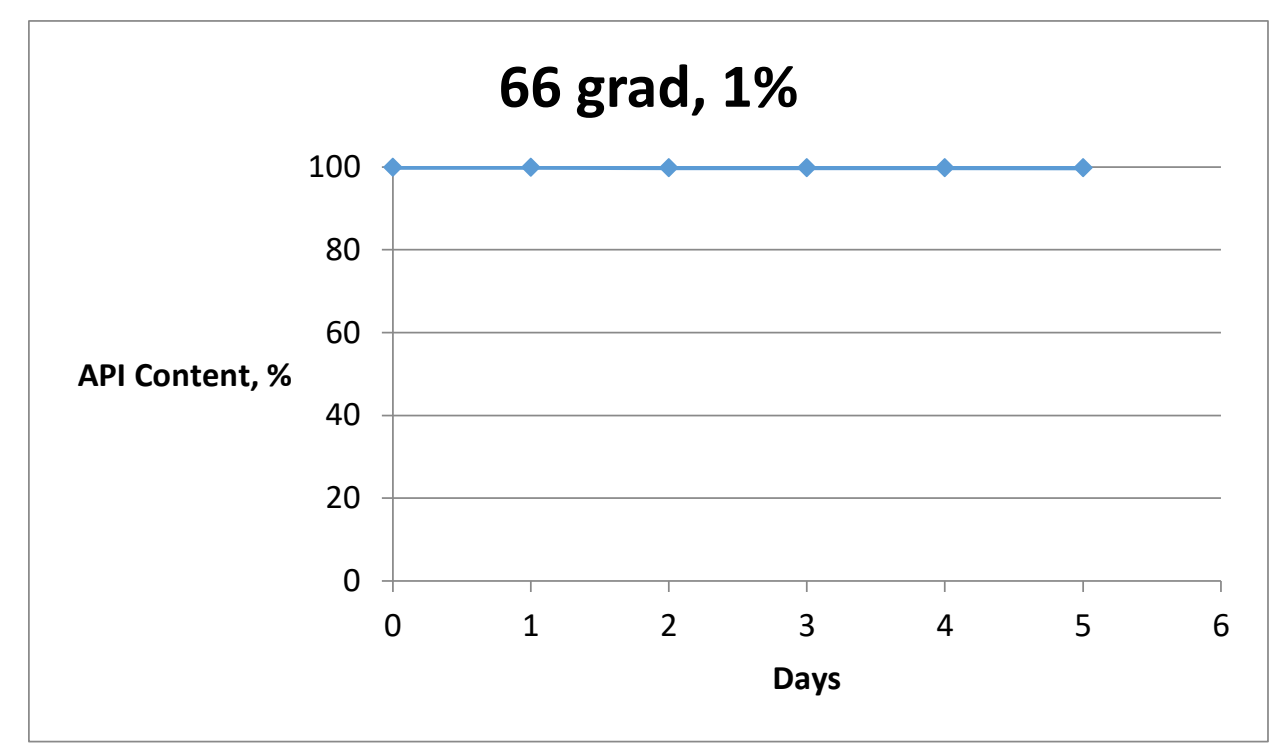

Figure 2. The API degradation curve in the $1 \%$ model solution for injection at a temperature $66{ }^{\circ} \mathrm{C}$

\section{Oxidative degradation}

The effect of $3 \%$ hydrogen peroxide over 6 days results in a decrease in the concentration of API about 2 times (Fig. 3).

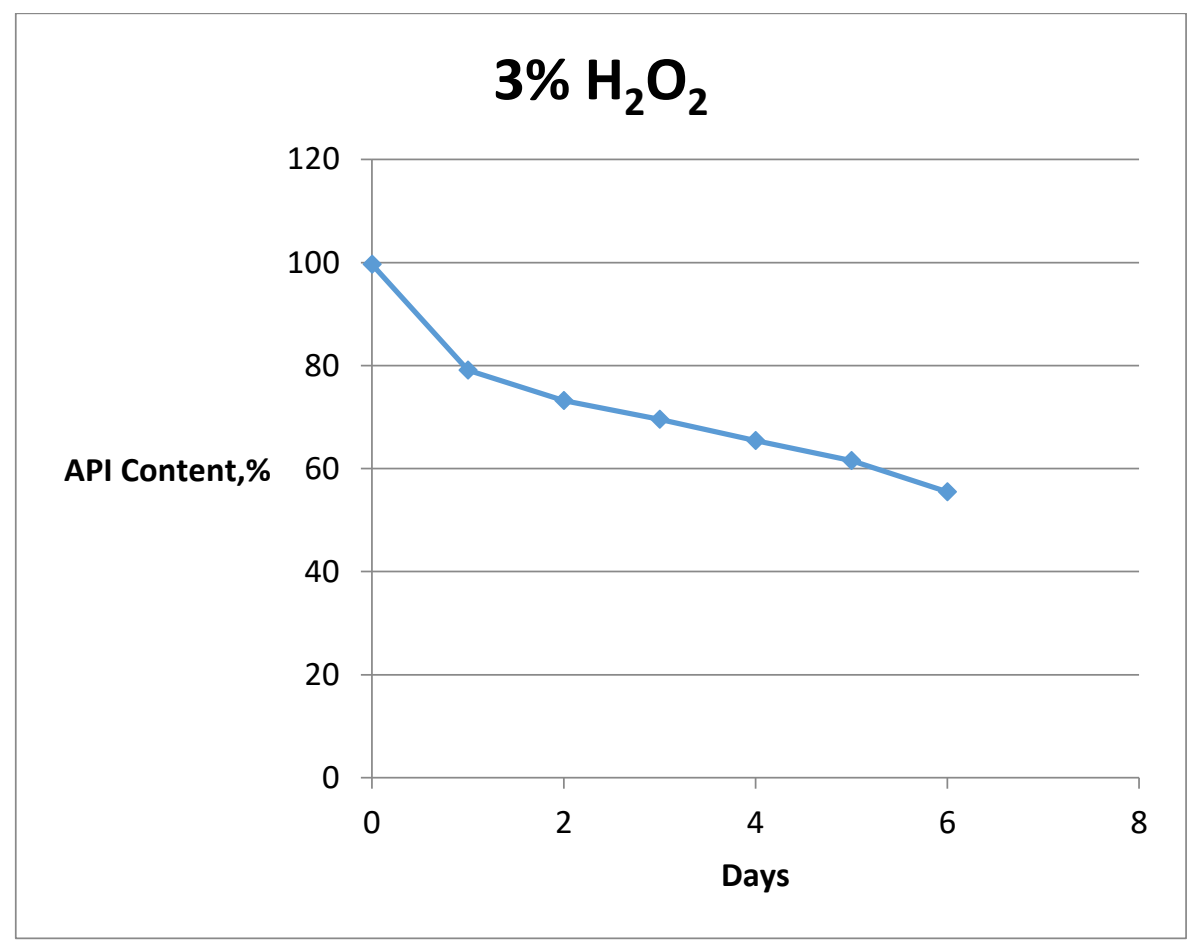

Figure 3. The API degradation curve under action $3 \% \mathrm{H}_{2} \mathrm{O}_{2}$ 


\section{Ultraviolet (UV) degradation}

UV light irradiation causes the decomposition of the $0.1 \%$ solution during four days at more than $40 \%$ (Fig. 4).

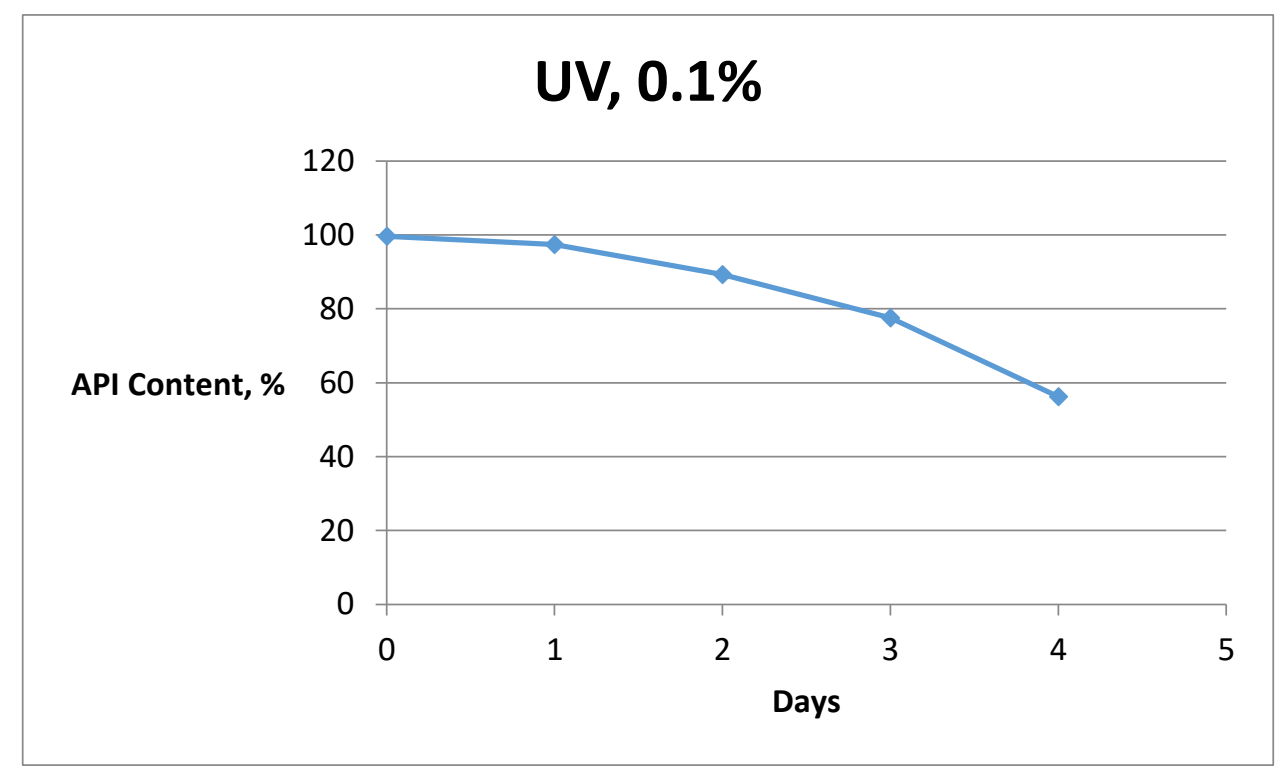

Figure 4. The API degradation curve in $0.1 \%$ solution

At the same time, for $1 \%$ solution the concentration was decreased about $20 \%$ (Fig. 5). The API content was not changed during irradiation of dry substance for 4 days.

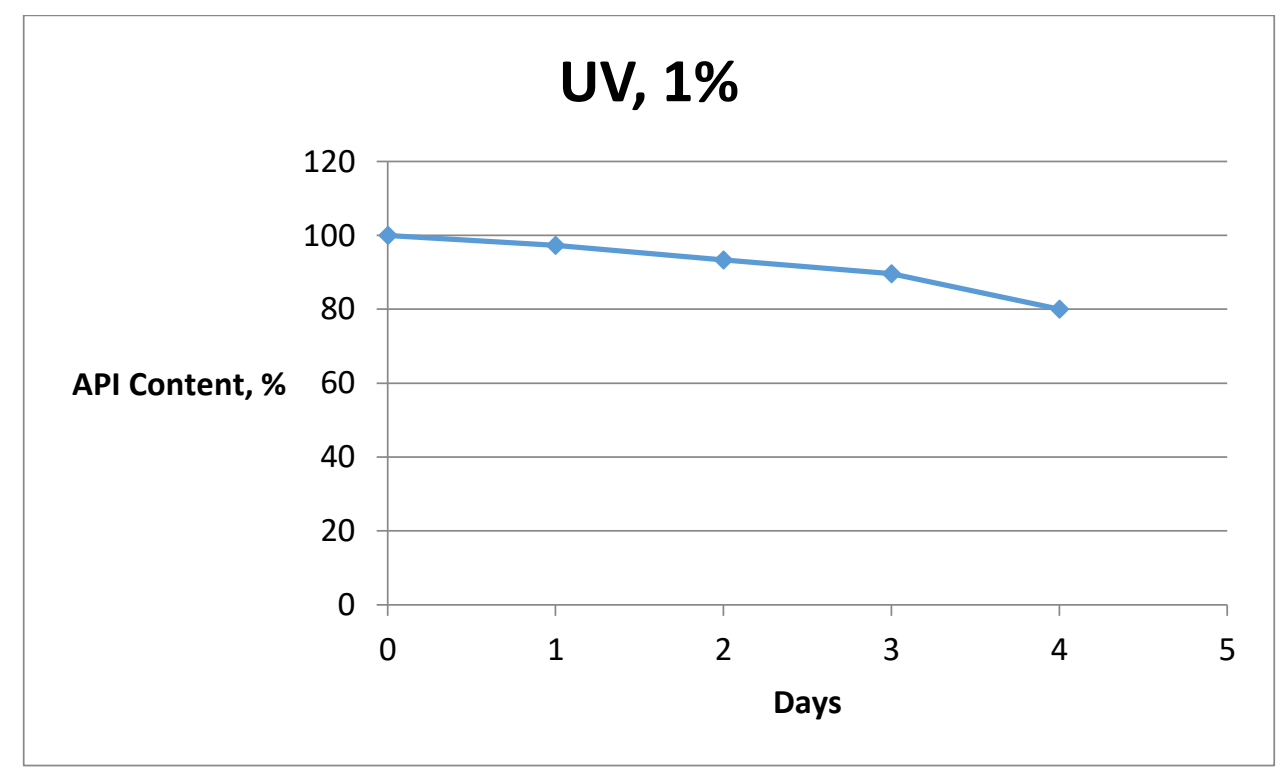

Figure 5. The API decomposition curve in the $1 \%$ solution for injection. 


\section{Acid hydrolysis}

Under the action of $0.1 \mathrm{M}$ solution of chloride acid API immediately decomposes with formation 2-((5-(furan-2-yl)-4-phenyl-4H-1,2,4-triazol-3-yl)thio)acetic acid, which is insoluble in water. So, the study of exposure of $0.1 \mathrm{M}$ chloride acid was finished at this step.

Alkaline hydrolysis

Under the action of $0.1 \mathrm{M}$ solution of sodium hydroxide, the content of the API was not changed for 6 days.

\section{Determination of the structure of degradation products}

Possible structures of compounds formed as a result of API degradation under stress conditions was proposed after study of the mass spectra of the corresponding chromatography peaks.

The structure determination of API degradation products formed by the action of $3 \%$ hydrogen peroxide.
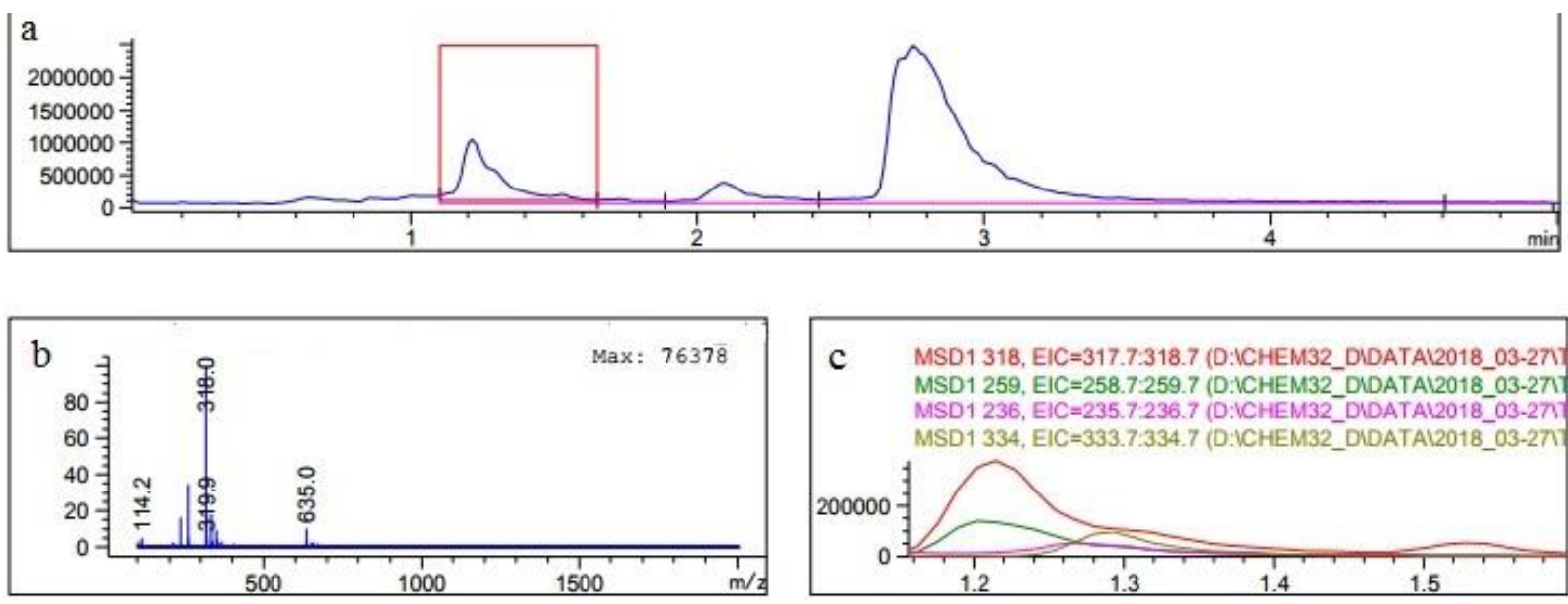

Figure 6. The TIC chromatogram of API degradation products formed by action of $3 \% \mathrm{H}_{2} \mathrm{O}_{2}$ at $150 \mathrm{~V}$ (a). Mass spectrum of peak at 1.219 min (b). EIC chromatogram (c).

Chromatography of the degradation products appeared after action of $3 \% \mathrm{H}_{2} \mathrm{O}_{2}$ shown two peaks (Fig. 6). First peak (at $1.219 \mathrm{~min}$ ) was not pure. The most intensive peak in extracted ion chromatogram (EIC) had $\mathrm{m} / \mathrm{z}=318$. It corresponded to the sulfoxide (Fig. 7). It is known reaction of sulfoxide formation from organic compounds of sulfur with valence two by the influence of the $\mathrm{H}_{2} \mathrm{O}_{2}$ solution [12]. 

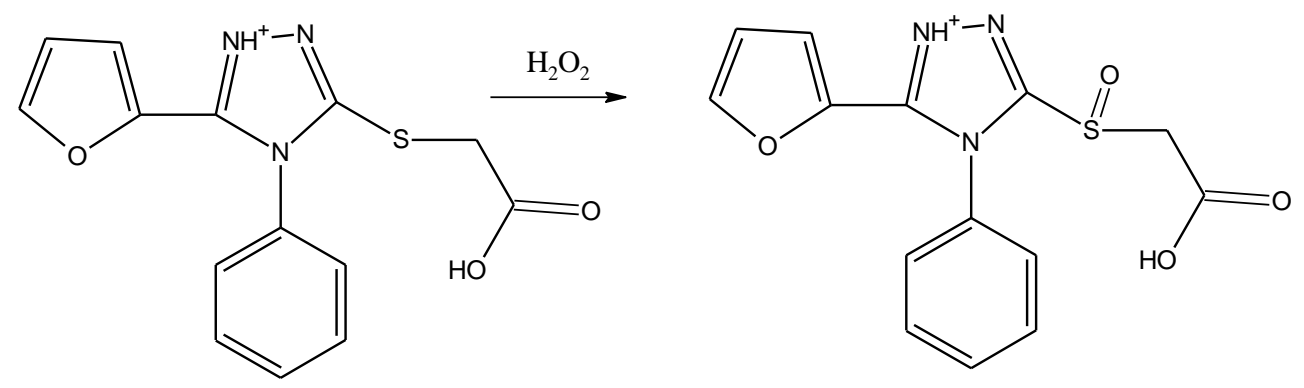

Monoisotopic Mass $=318.054302 \mathrm{Da}$

Figure 7. Formaton of 3-[(carboxymethyl)sulfinyl]-5-(furan-2-yl)-4-phenyl-4H-1,2,4-triazol-1-ium cation $(\mathrm{m} / \mathrm{z}=318)$.
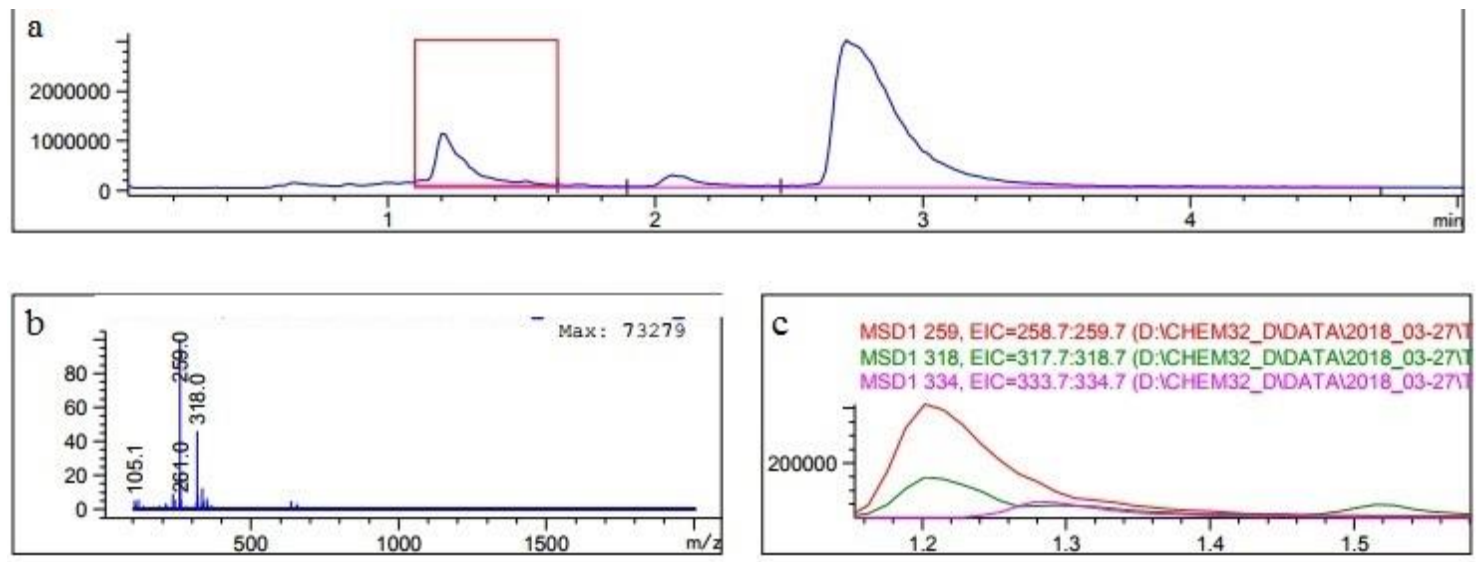

Figure 8. The TIC chromatogram of API degradation products formed by action of $3 \% \mathrm{H}_{2} \mathrm{O}_{2}$ at $200 \mathrm{~V}$ (a). Mass spectrum of peak at 1.217 min (b). EIC chromatogram (c).

When fragmentation voltage was increased till $200 \mathrm{~V}$ the ion with the $\mathrm{m} / \mathrm{z} 259$ in the mass spectra of first peak was appeared (Fig.8). The possible structure of this ion is presented at Fig. 9.
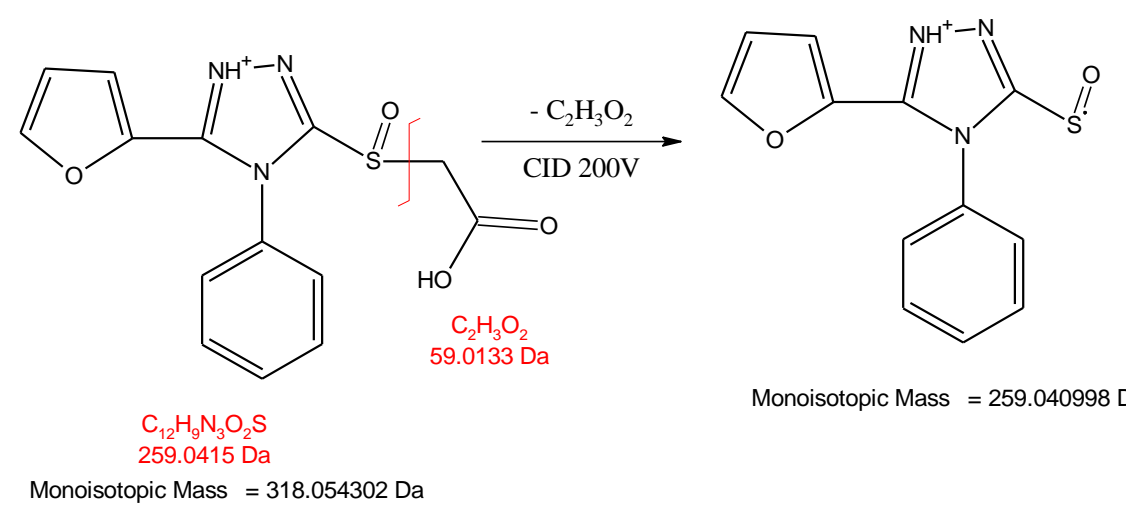

Monoisotopic Mass $=259.040998 \mathrm{Da}$

Monoisotopic Mass $=318.054302 \mathrm{Da}$

Figure 9. Transformation of cation with $\mathrm{m} / \mathrm{z} 318$ during fragmentation in CID at 200V 
Second peak of the degradation product was at $2.140 \mathrm{~min}$ (Fig. 10).
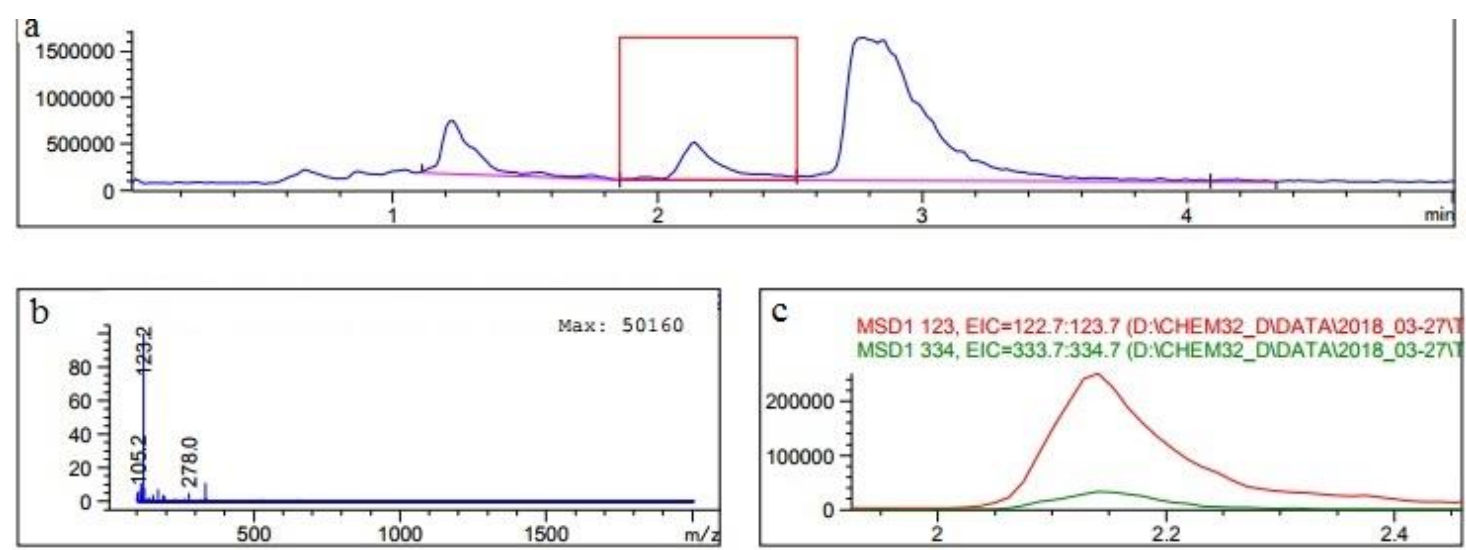

Figure 10. The TIC chromatogram of API degradation products formed by action of $3 \% \mathrm{H}_{2} \mathrm{O}_{2}$ at $100 \mathrm{~V}$ (a). Mass spectrum of peak at $2.140 \mathrm{~min}$ (b).EIC chromatogram (c).

Quazimolecular ion with $\mathrm{m} / \mathrm{z}=334$ correspond to the sulfone which was formed at the second step oxidation by the $\mathrm{H}_{2} \mathrm{O}_{2}$ (Fig. 11). It is well-known reaction [12].
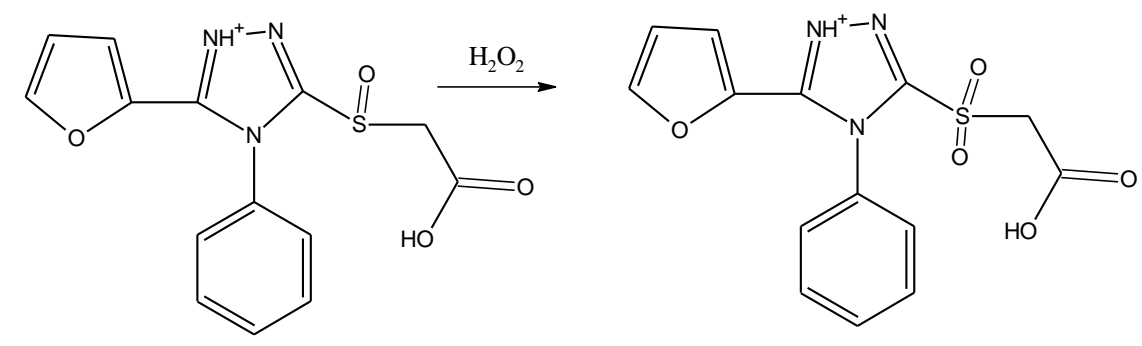

Monoisotopic Mass $=334.049217 \mathrm{Da}$

Figure 11. Formation of 3-[(carboxymethyl)sulfonyl]-5-(furan-2-yl)-4-phenyl-4H-1,2,4-triazol-1-ium cation $(\mathrm{m} / \mathrm{z}=334)$.

There are two fragment ions present in mass spectra of second peak at $100 \mathrm{~V}(\mathrm{~m} / \mathrm{z}=278.0$ and $\mathrm{m} / \mathrm{z}=123.2$ ). Possible structure of first ion present at Fig. 12. 


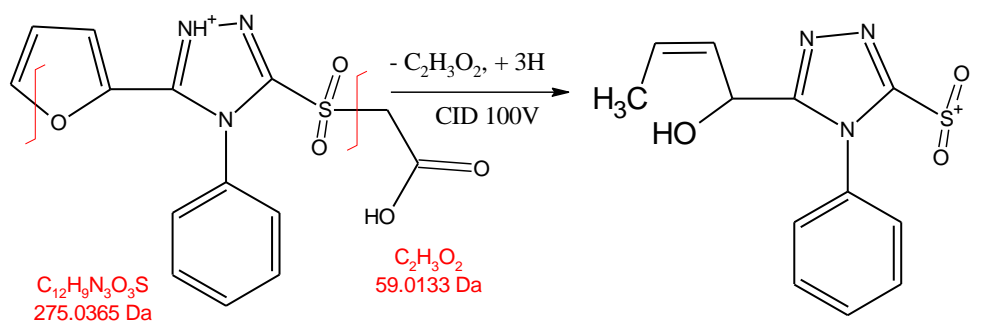

Monoisotopic Mass $=334.049217 \mathrm{Da}$

Monoisotopic Mass $=278.059388 \mathrm{Da}$

Figure 12. Converting of cation with $\mathrm{m} / \mathrm{z} 344$ during fragmentation in CID at $100 \mathrm{~V}$ to product the cation with $\mathrm{m} / \mathrm{z} 278$.

Reaction formation of the ion with m/z 123 present at Fig.13.
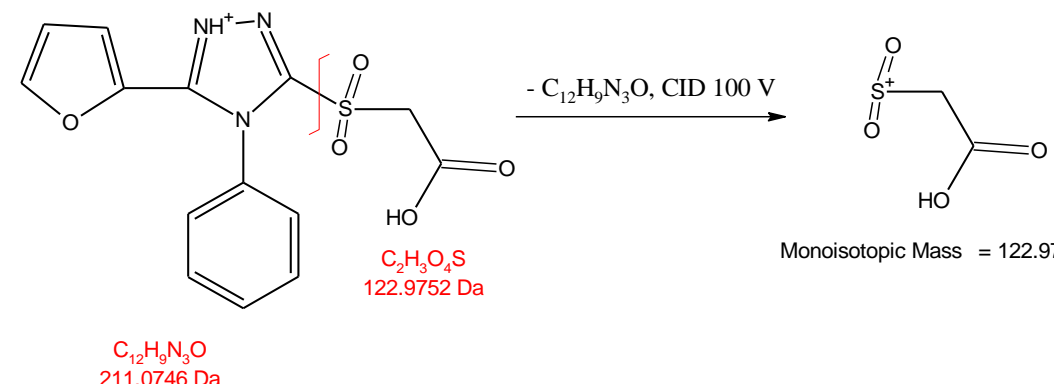

Monoisotopic Mass $=122.974655 \mathrm{Da}$ $\mathrm{C}_{12} \mathrm{H}_{9} \mathrm{~N}_{3} \mathrm{O}$

Figure 13. Transformation of cation with $\mathrm{m} / \mathrm{z} 344$ during fragmentation in CID at $100 \mathrm{~V}$ to product the cation with $\mathrm{m} / \mathrm{z} 123$.

The structure determination of API degradation products formed by the influence of UV radiation on $0.1 \%$ solution.
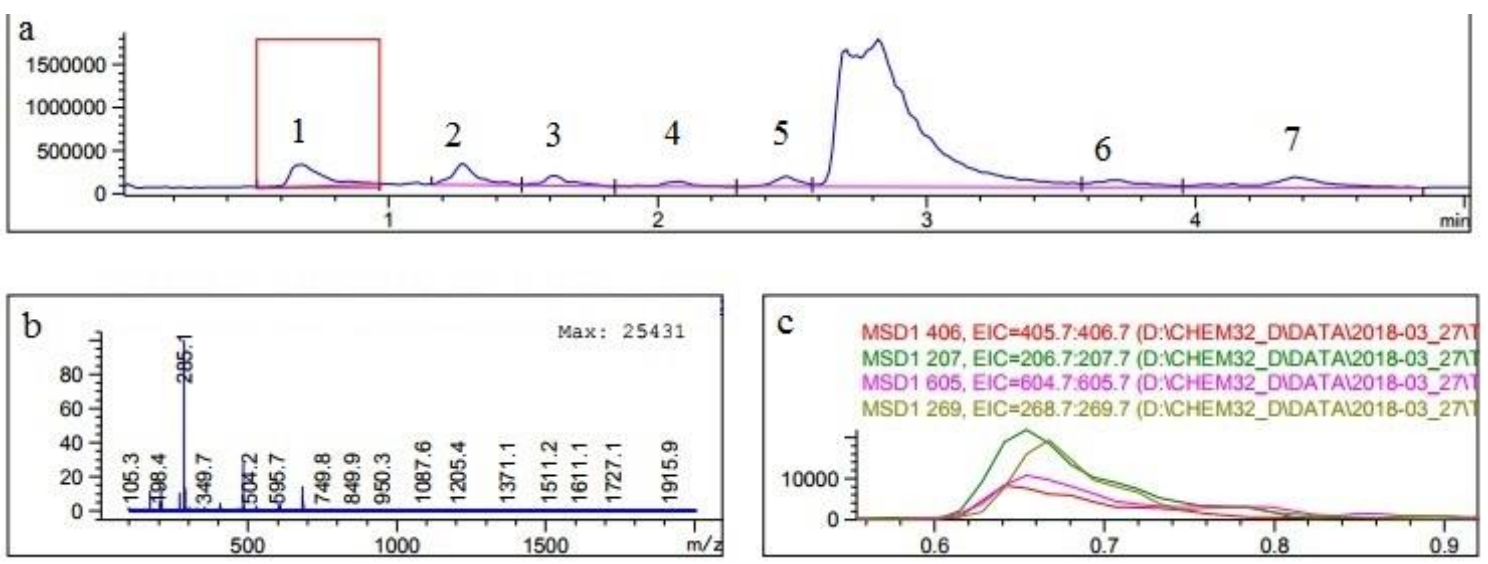

Figure 14. The TIC chromatogram of API degradation products formed by UV radiation (fragmentation voltage 100V) (a). Mass spectrum of peak (1) at 0.675 min (b). EIC chromatogram (c). 

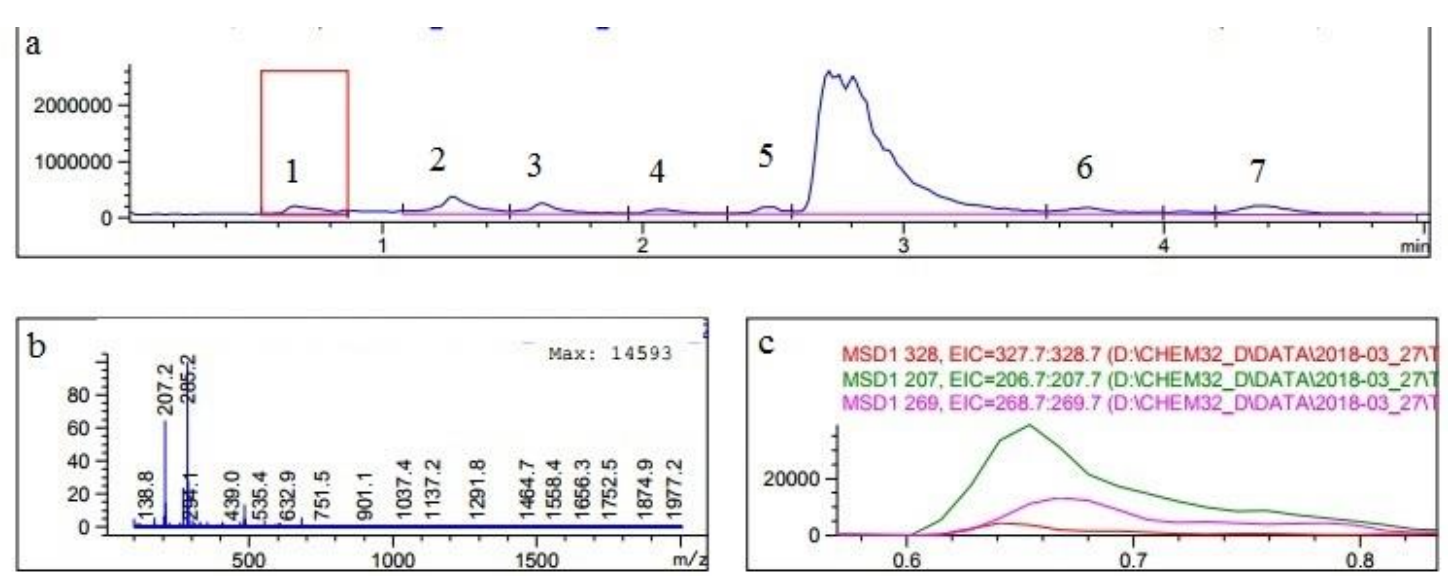

Figure 15. The TIC chromatogram of API degradation products formed by UV radiation (fragmentation voltage 150V) (a). Mass spectrum of peak (1) at $0.670 \mathrm{~min}$ (b). EIC chromatogram (c).

The first peak was not identified (Fig. 15). The monoisotope mass $\mathrm{m} / \mathrm{z}=285.2$ and $\mathrm{m} / \mathrm{z}=207.2$ in the mass spectrum of the unidentified peak (1) was observed (Fig.14, 15).
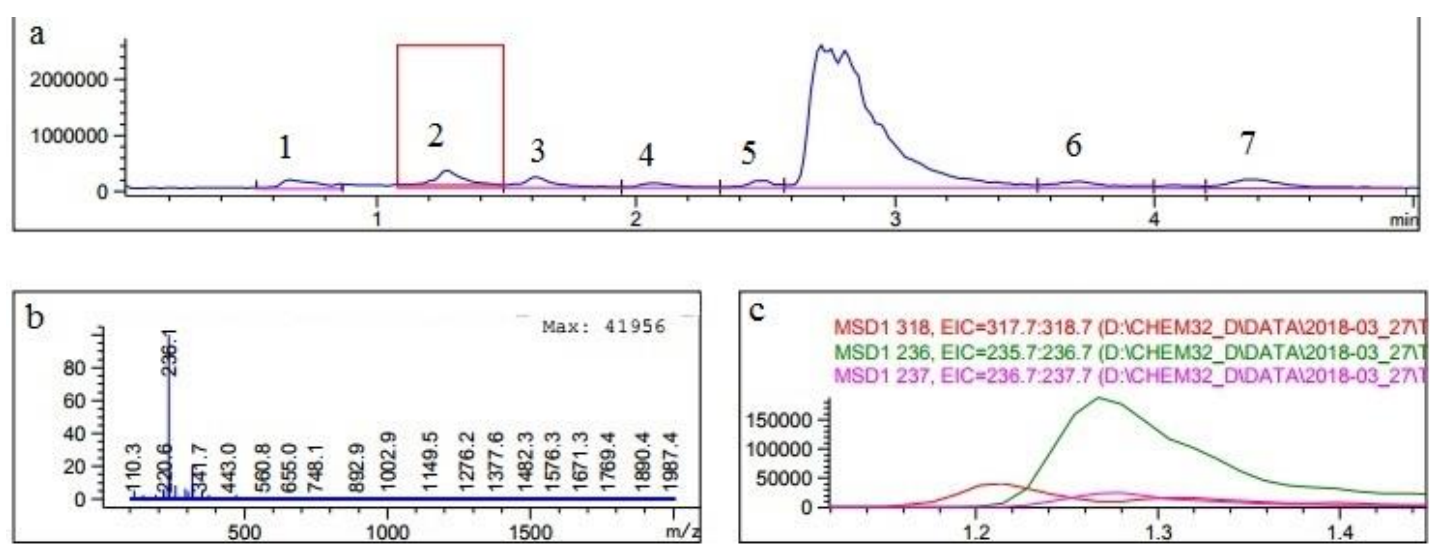

Figure 16. The TIC chromatogram of API degradation products formed by the action of UV radiation (fragmentation voltage 150V) (a). Mass spectrum of peak (2) at 1.275 min (b). EIC chromatogram (c).

Sulfoxide was also observed at $150 \mathrm{~V}$ in API degradation products formed by the action of UV radiation. The retention time was close to 1.2 (peak 2), m/z 318 (Fig. 16).

There was an impurity that is associated with the cleavage of the furan cycle to form the corresponding structure with $\mathrm{m} / \mathrm{z} 236.1$ (Fig.17). On the second day of irradiation there was a peak of dimer ion with $\mathrm{m} / \mathrm{z} 471$, which confirms that the quasimolecular ion has a mass 236 . 


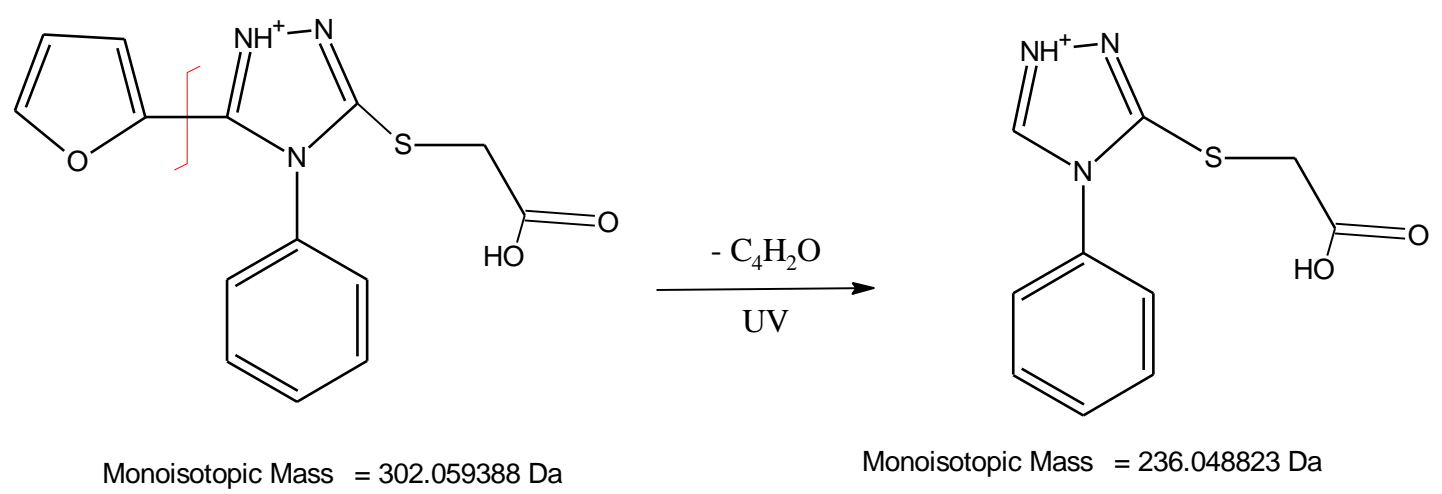

Figure 17. Possible way of degradation of the API at UV radiation influence with cleavage of the furan ring.
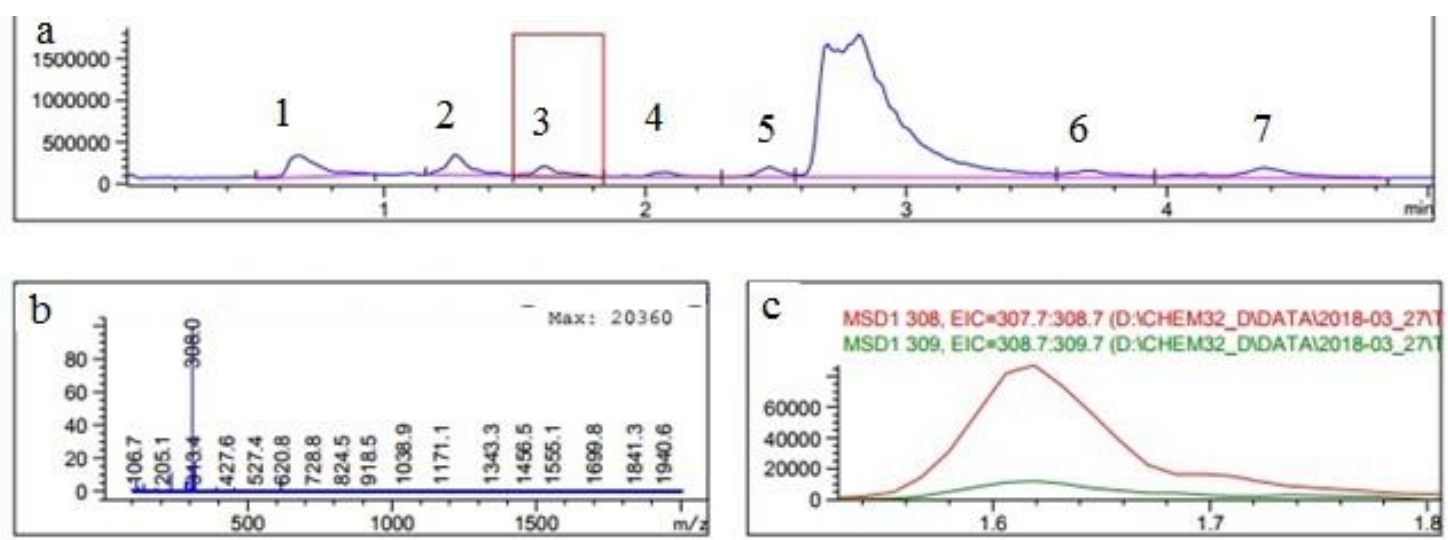

Figure 18. The TIC chromatogram of API degradation products formed by the action of UV radiation (fragmentation voltage 100V) (a). Mass spectrum of peak (3) at $1.616 \mathrm{~min}$ (b).EIC chromatogram (c).

Possible structures of the ion with m/z 308 (Fig. 18) $\left([\mathrm{M}+\mathrm{H}]^{+}\right)$proposed at Fig. 19. They are formed as a result of the reduction and opening of furan cycle. The dimeric ion with $\mathrm{m} / \mathrm{z} 615\left([2 \mathrm{M}+\mathrm{H}]^{+}\right)$ was detected in the mass spectrum on the second day of irradiation. The presence of the corresponding dimer ion confirms that the ion with $\mathrm{m} / \mathrm{z} 308$ is a quasimolecular ion. 


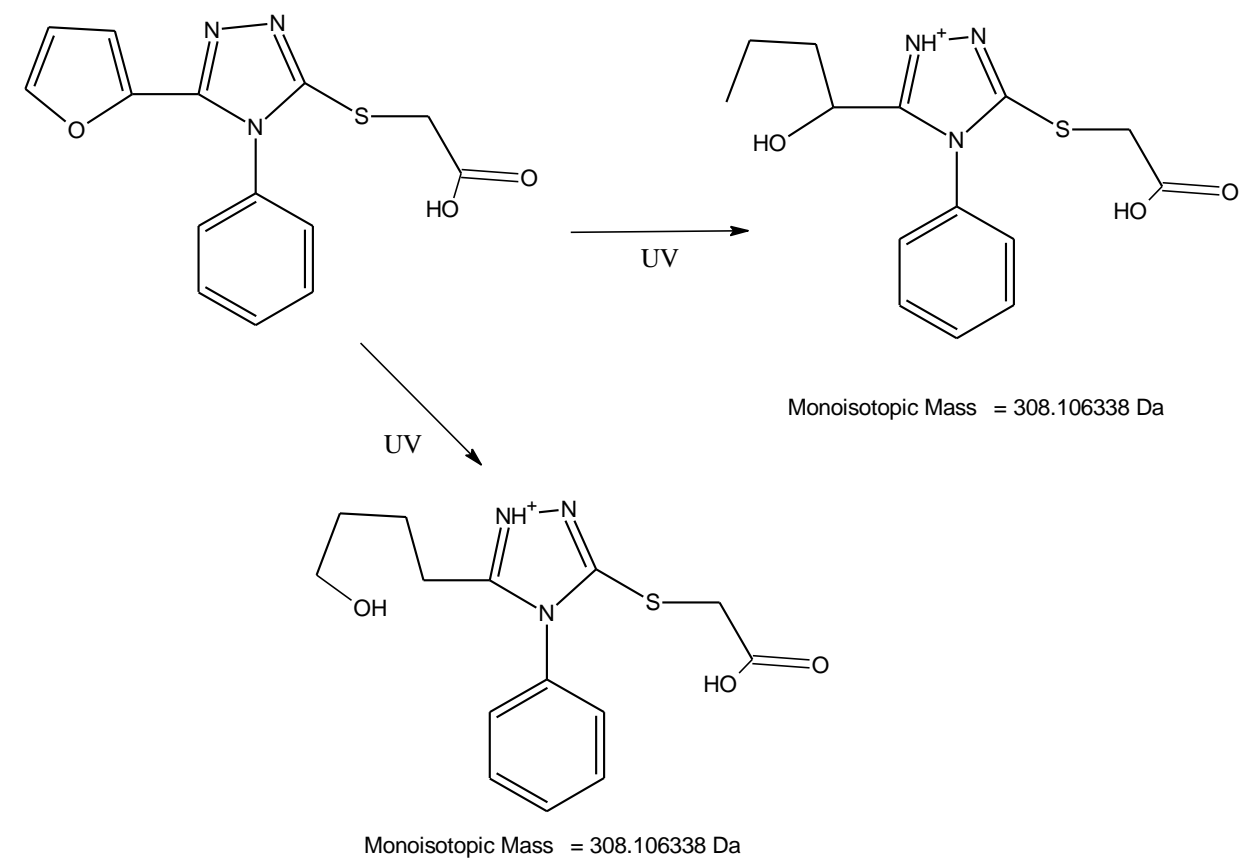

Figure 19. Possible API photodegradation pathway with formation of the product with molecular mass 308.1
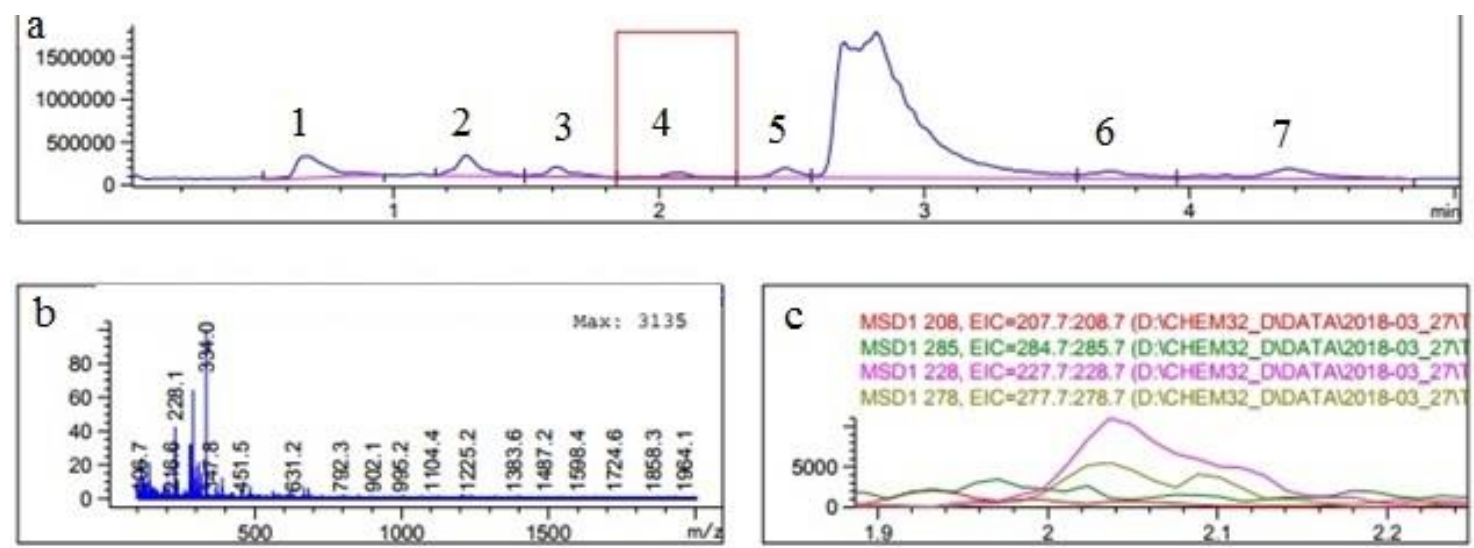

Figure 20. The TIC chromatogram of API degradation products formed by the action of UV radiation (fragmentation voltage 100V) (a). Mass spectrum of peak (4) at 2.070 min (b).EIC chromatogram (c).

There is also sulfone in products of the photodegradation, the retention time is approximately 2.1, m/z 334 (Fig.20). 

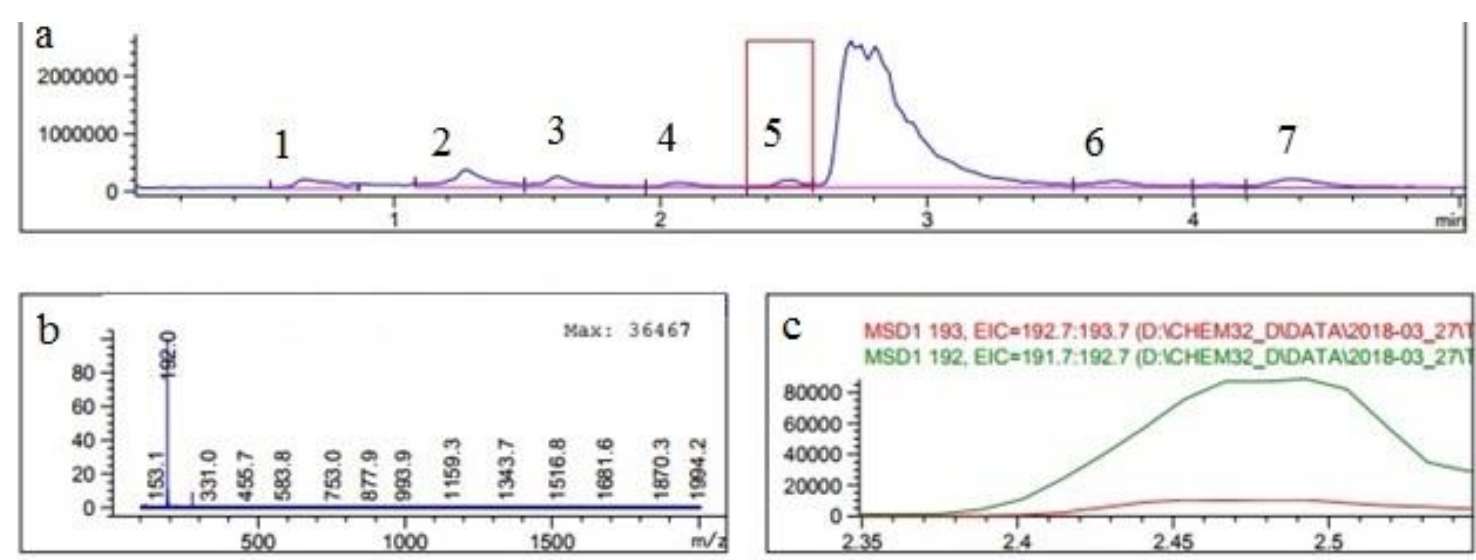

Figure 21. The TIC chromatogram of API degradation products formed by the action of UV radiation (fragmentation voltage 150V) (a). Mass spectrum of peak (5) at $2.478 \mathrm{~min}$ (b).EIC chromatogram (c).

An impurity with a retention time approximately $2.5 \mathrm{~min}$ and m/z 192 was observed (Fig. 21). It is the product of the breakaway of the furan cycle, as well as carbon dioxide (decarboxylation) from protonated 2-((5-(furan-2-yl)-4-phenyl-4H-1,2,4-triazol)-3-yl) acetate acid (Fig. 22).

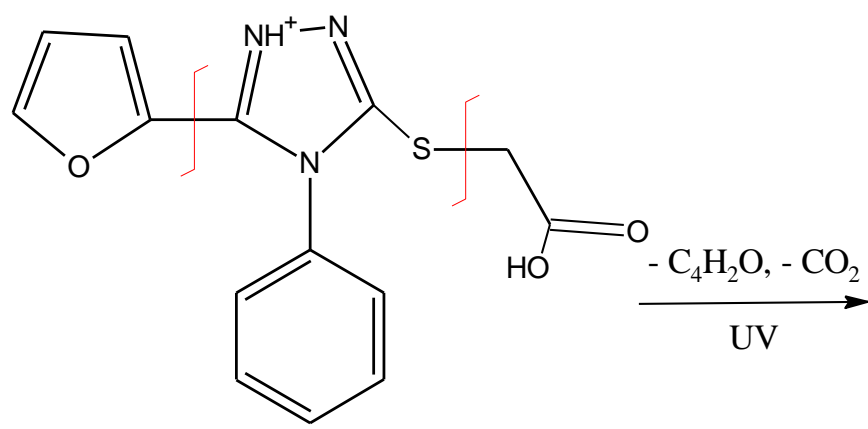

Monoisotopic Mass $=302.059388 \mathrm{Da}$

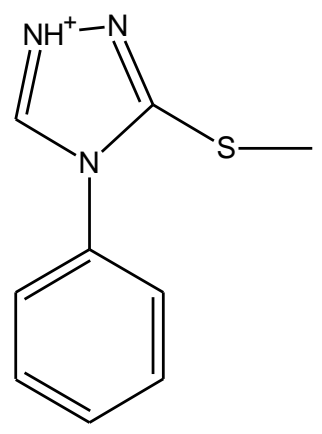

Monoisotopic Mass $=192.058994 \mathrm{Da}$

Figure 22. Cleavage of furan cycle and decarboxilation of API

The formation of the thione under the influence of UV radiation was observed. The 5-(furan-2yl)-4-phenyl-2,4-dihydro-3H-1,2,4-triazole-3-thione is precursor in the synthesis of API [10, 11]. It was confirmed by the retention time and $\mathrm{m} / \mathrm{z}$. The retention time corresponds to the retention time from chromatography of the standard solution of the corresponding thione $(3.7 \mathrm{~min}), \mathrm{m} / \mathrm{z}$ of quasimolecular ion equals 244, which corresponds to the molecular weight of the protonated compound (Fig.23, 24). 

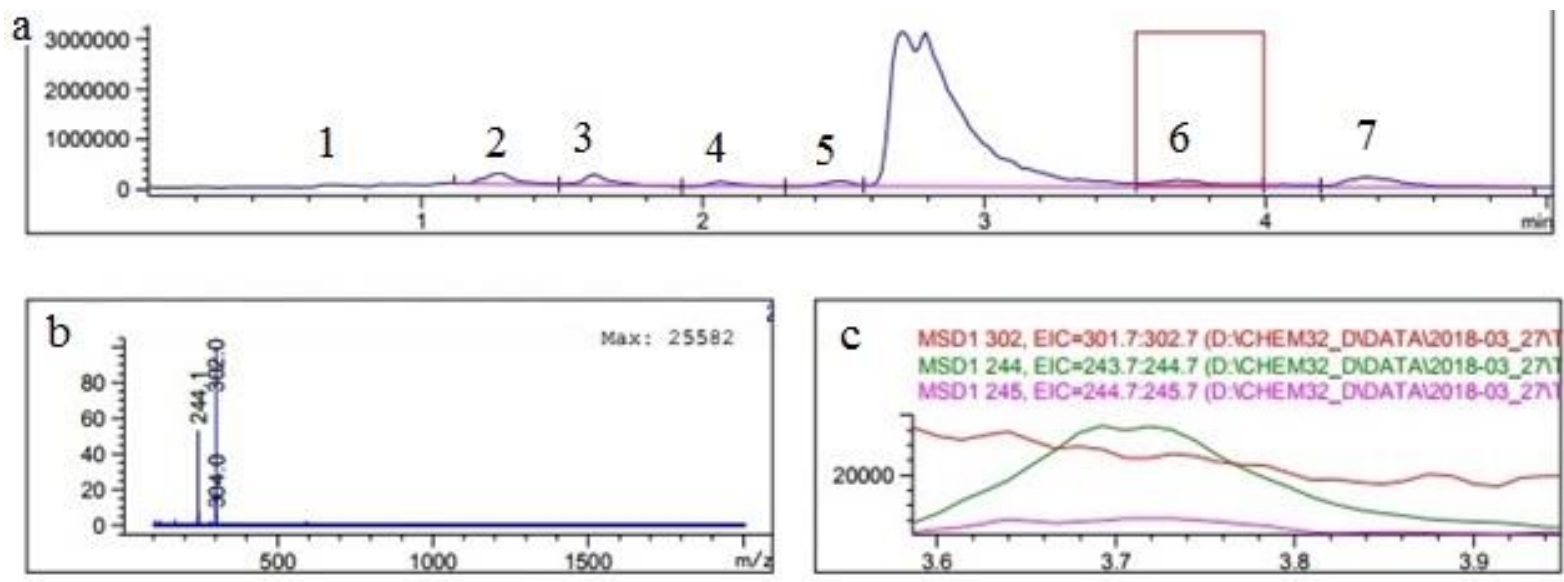

Figure 23. The TIC chromatogram of API degradation products formed by the action of UV radiation (fragmentation voltage 200V) (a). Mass spectrum of peak (6) at $3.695 \mathrm{~min}$ (b).EIC chromatogram (c).

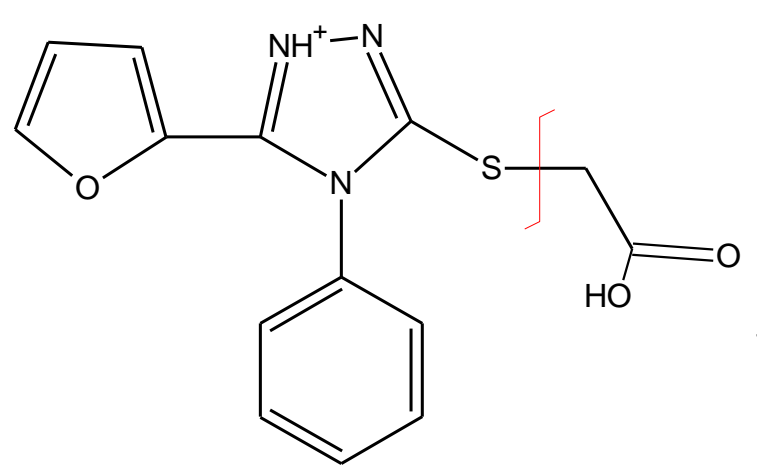

Monoisotopic Mass $=302.059388 \mathrm{Da}$

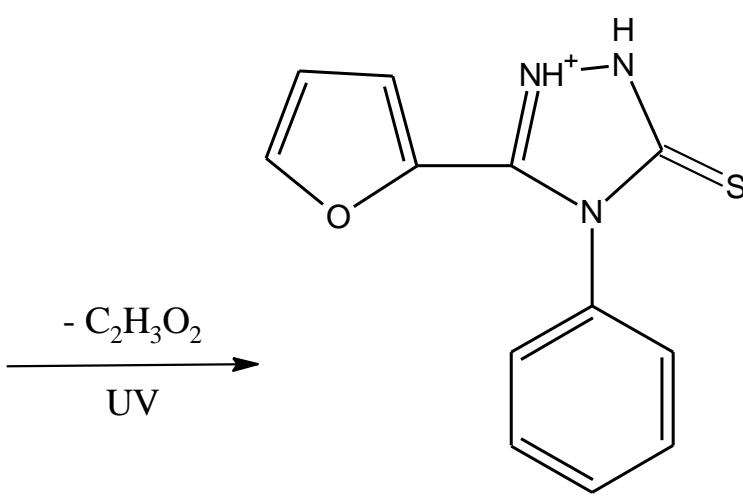

Monoisotopic Mass $=244.053908 \mathrm{Da}$

Figure 24. The 5-(furan-2-yl)-4-phenyl-2,4-dihydro-3H-1,2,4-triazole-3-thione formation. 

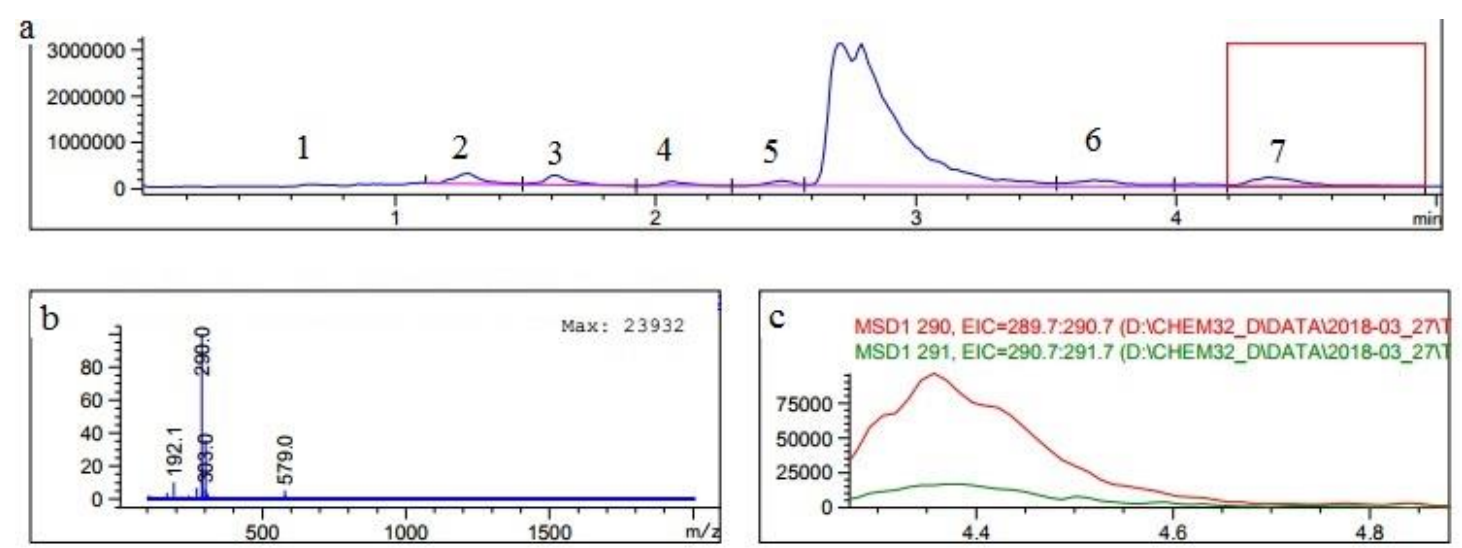

Figure 25. The TIC chromatogram of API degradation products formed by the action of UV radiation (fragmentation voltage 200V) (a). Mass spectrum of peak (7) at $4.363 \mathrm{~min}$ (b). EIC chromatogram (c).

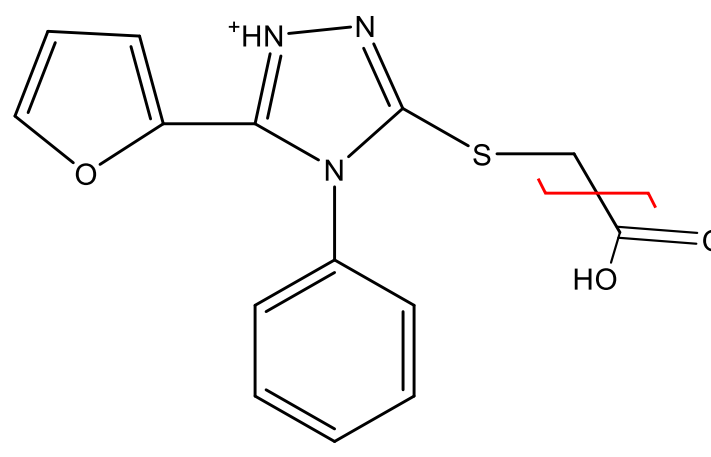

Monoisotopic Mass $=302.059388 \mathrm{Da}$

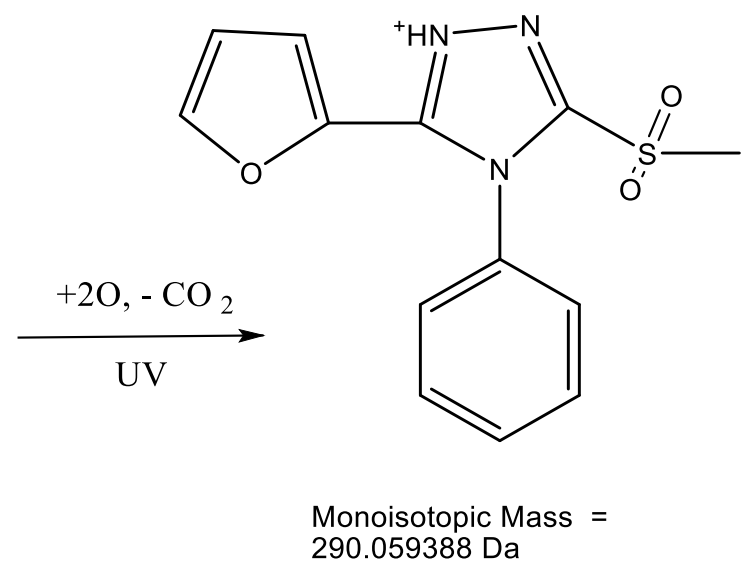

$290.059388 \mathrm{Da}$

Figure 26. Formation of decarboxilated sulfone.

Anion with $\mathrm{m} / \mathrm{z}=290.0$ was formed in the ion source $\left([\mathrm{M}+\mathrm{H}]^{+}\right)$, as well as dimer ion with $\mathrm{m} / \mathrm{z}$ $579.0\left([2 \mathrm{M}+\mathrm{H}]^{+}\right)$, which confirms that the ion with $\mathrm{m} / \mathrm{z} 290$ is a quasimolecular ion (Fig. 25). The carbon dioxide was eliminated, and the sulfur atom was oxidized under the action of UV light to form the methylsulfone with the monoisotope mass 289.0 (Fig. 26). 
Table 2. Impurities were formed in stressful conditions.

\begin{tabular}{|c|c|c|c|c|c|c|}
\hline \# & Compound & $\begin{array}{l}3 \% \\
\mathrm{H}_{2} \mathrm{O}_{2} \\
\end{array}$ & UV & $\begin{array}{c}\text { Retention } \\
\text { time }\end{array}$ & $\begin{array}{c}\text { m/z quasimolecular } \\
\text { ion }\end{array}$ & $\begin{array}{c}\text { Monoisotope } \\
\text { molecular weight }\end{array}$ \\
\hline 0 & API & & & 2.8 & 302 & 301 \\
\hline 1 & $\begin{array}{l}\text { 2-((5-(furan-2-yl)-4-phenyl- } \\
4 H-1,2,4-\text { triazol-3- } \\
\text { yl)sulfinyl)acetic acid }\end{array}$ & $+^{*}$ & + & 1.2 & 318 & 317 \\
\hline 2 & $\begin{array}{l}\text { 2-((5-(furan-2-yl)-4-phenyl- } \\
4 H \text {-1,2,4-triazol-3- } \\
\text { yl)sulfonyl)acetic acid }\end{array}$ & + & + & 2.1 & 334 & 333 \\
\hline 4 & $\begin{array}{l}\text { 2-((4-phenyl-4H-1,2,4- } \\
\text { triazol-3-yl)thio)aceticacid }\end{array}$ & $-* *$ & + & 1.3 & 236 & 235 \\
\hline 5 & $\begin{array}{l}\text { 2-((5-(1-hydroxybutyl)-4- } \\
\text { phenyl-4H-1,2,4-triazol-3- } \\
\text { yl)thio)acetic acid, 2-((5-(4- } \\
\text { hydroxybutyl)-4-phenyl-4H- } \\
\text { 1,2,4-triazol-3-yl)thio)acetic } \\
\text { acid }\end{array}$ & - & + & 1.6 & 308 & 307 \\
\hline 6 & $\begin{array}{l}\text { 3-(methylthio)-4-phenyl-4H- } \\
\text { 1,2,4-triazole }\end{array}$ & - & + & 2.5 & 192 & 191 \\
\hline 7 & $\begin{array}{l}\text { 5-(furan-2-yl)-4-phenyl-2,4- } \\
\text { dihydro-3H-1,2,4-triazole-3- } \\
\text { thione }\end{array}$ & - & + & 3.7 & 244 & 243 \\
\hline 8 & $\begin{array}{l}\text { 3-(furan-2-yl)-5- } \\
\text { (methylsulfonyl)-4-phenyl- } \\
\text { 4H-1,2,4-triazole }\end{array}$ & - & + & 4.4 & 290 & 289 \\
\hline
\end{tabular}

Influence of the sodium hydroxide, hydrochloride acid, $3 \% \mathrm{H}_{2} \mathrm{O}_{2}$, temperature, $\mathrm{UV}$ radiation on piperidine 2-((5-(furan-2-yl)-4-phenyl-4H-1,2,4-triazol)-3-yl) acetate substance, $0.1 \%$ solution and $1 \%$ solution for injections were studied. Dependence of the quantitative content of the piperidinium 2-((5(furan-2-yl)-4-phenyl-4H-1,2,4-triazol)-3-yl) acetate from exposition time was determined. The composition of degradation products formed under the actionof anoxidizer was established $\left(3 \% \mathrm{H}_{2} \mathrm{O}_{2}\right)$. This is sulfoxide and sulfone corresponding to the API. The composition of degradation products which were formed under the influence of UV radiation was proposed.

\section{ACKNOWLEDGEMENTS}

We acknowledge complete support of the Zaporozhye State Medical University. We thank rector of Zaporozhye State Medical University Prof. Yu. M. Kolesnyk for his help and support.

There are no conflicts of interest have been declared.

\section{REFERENCES}

1. Sehrawat, R., Maithani, M., Singh,R. (2010). Regulatory Aspects in Development of StabilityIndicating Methods: A Review. Chromatographia, 72 (1/2), 1-6. 
2. Blessy, M, Ruchi, D.P., Prajesh, N.Pr., Agrawal, Y.K. (2014). Development of forced degradation and stability indicating studies of drugs-A review. Journal of Pharmaceutical Analysis; 4(3), 159165.

3. Klick, S., Muijselaar, P.G., Waterval, J., Eichinger, Th., Korn, C., Gerding, Th.K., Debets, Al.J., Van de Griend, C.S., Van den Beld, C., Somsen, G.W. and De Jong, G.J. (2005). Stress Testing of Drug Substances and Drug Products. Pharmaceutical Technology, FEBRUARY; 48-66.

4. Chakravarthy, V.A., Sailaja, B.B.V., Kumar, A.P. (2015). Stability-Indicating RP-HPLC Method for Simultaneous Estimation of Enrofloxacin and Its Degradation Products in Tablet Dosage Forms. Journal of Analytical Methods in Chemistry, 2015, 1-11.

5. Ahirrao, V.K., Patil, C.S., Bembalkar, S.R., Katariya, M.V., Sonnekar, V.S., Marathe, R.P., Nawale,R. B.,Pawar, R. P.(2012). Stress degradation studies of dronedarone in pharmaceutical dosage form by a validated stability-indicating LC method. Journal of the Chilean Chemical Society, 57(3); $1272-1276$.

6. Patel, J. K., Patel, N. K. (2014). Stability-Indicating RP-HPLC Method for the Determination of Ambrisentan and Tadalafil in Pharmaceutical Dosage Form. Scientia Pharmaceutica, 82, 749-763.

7. Parchenko, V. V., Panasenko, O. I., Knysh, E. G., Vasyuk S. O., Tarkhanova, O. O. (2009). Working out of methods quantitative determination piperidiniy 2-[5-(furan-2-il)-4-phenil-1,2,4-triazol-3ilthio]acetate in the substance. Ukrainskyi biofarmatsevtychnyi zhurnal, 4, 44-45.

8. Parchenko, V.V., Panasenko, O.I., Knysh, E.G., Vasiuk, S.O., Tarkhanova, O. O. (2009). Qualitative and quantitative determination of the Piperidinium 2-((5-(furan-2-yl)-4-phenyl- $4 \mathrm{H}$ 1,2,4-triazol-3-yl)thio)acetate 1\% and 2,5\% solutions. Zaporozhye medical journal, 3, 111-112.

9. Varynskyi, B. O., Parchenko, V.V., Kaplaushenko, A. G. (2017). Development and validation of HPLC-DAD method of determination piperidinium 2-((5-(furan-2-yl)-4-phenyl-4H-1,2,4-triazol-3yl)thio)acetate in $1 \%$ solution, Zaporozhye medical journal, 19 (6), 827-832.

10. Parchenko, V. (2006). Synthesis, physicochemical and biological properties of derivatives of 1,2,4triazoles-3-thione containing core furan. Candidate of Pharm Scithesis, Zaporozhye State Medical University, Zaporozhye, 208 p.

11. Parchenko, V. (2014). Synthesis, transformation, physico-chemical and biological properties in a number of 5-furyl-substituted 1,2,4-triazole-3-thiones. Dr. Pharmacist Sciences thesis, Zaporozhye State Medical University, Zaporozhye, $460 \mathrm{p}$.

12. Tietze, L.F., Eicher, Th. (1991). Reaktionen und Synthesen im organisch-chemischen Praktikum und Forschungs laboratorium. 2. Aufl., Georg Thieme Verlag, Stuttgart - NewYork. DM 68, 672 S. 